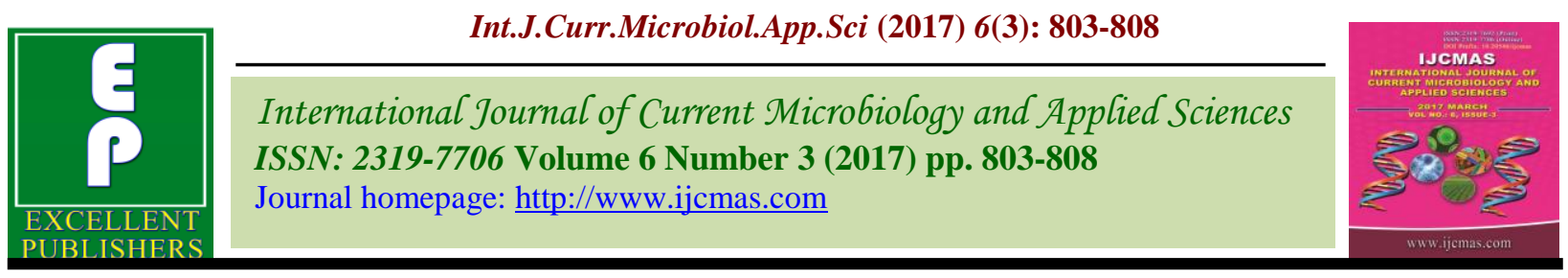

Original Research Article

https://doi.org/10.20546/ijcmas.2017.603.094

\title{
Effect of Various Integrated Nutrient Management Models on Growth and Yield of Wheat in Partially Reclaimed Sodic Soil
}

\author{
Hanumant Singh ${ }^{1}$, Abhinaw Kumar Singh ${ }^{2}$, Sarware Alam', Tejpratap Singh ${ }^{3}$, \\ V.P. Singh ${ }^{3}$, A.K.S. Parihar ${ }^{4}$ and Rajneesh Singh $^{3}$ \\ ${ }^{1}$ Department of Soil Science, ${ }^{2}$ Department of Agronomy, CCS HAU, HISAR-125004, India \\ ${ }^{3}$ Department of Agronomy, ${ }^{4}$ Department of Soil Science, NDUA\&T Kumarganj \\ Faizabad-224229 India \\ *Corresponding author
}

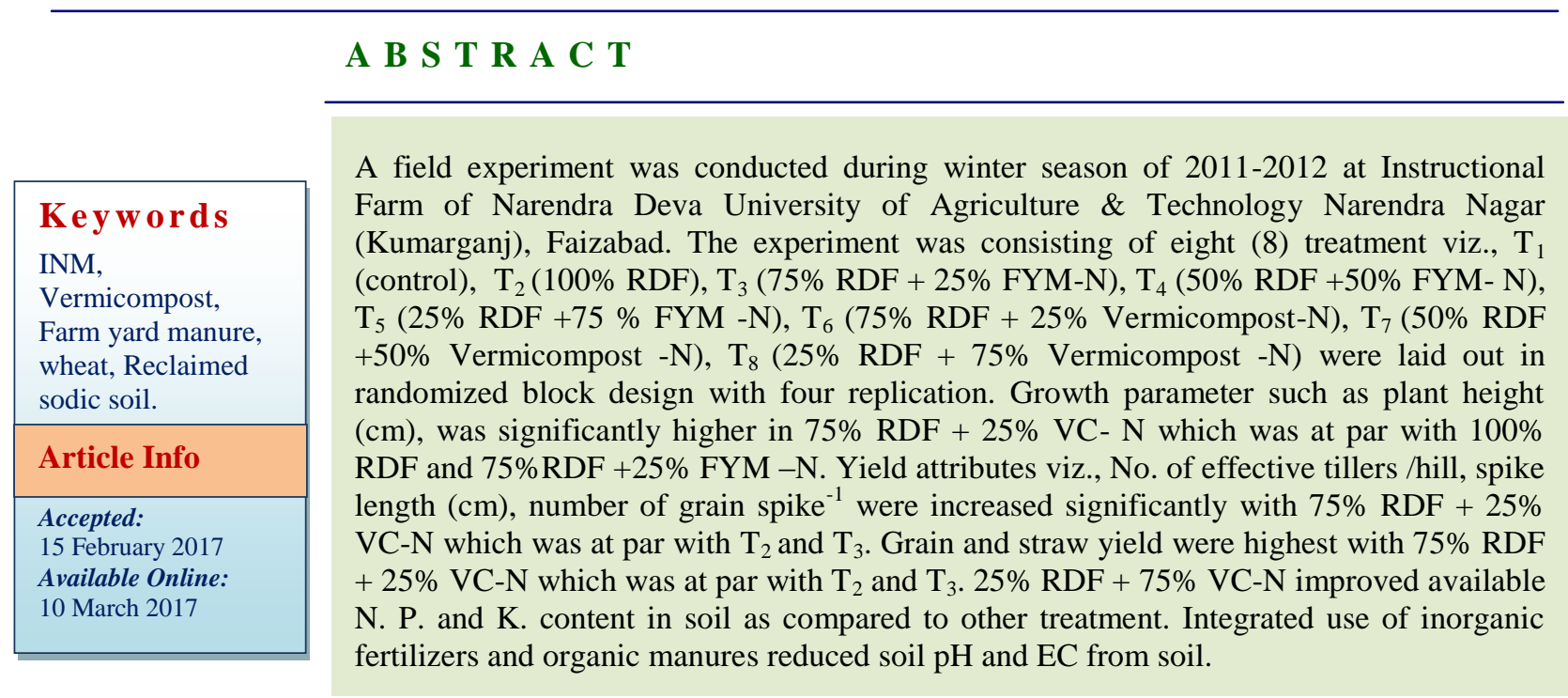

\section{Introduction}

Wheat is primarily grown in temperate regions at high altitude as well as medium altitude in tropical and sub-tropical regions. Wheat is a pre-dominant winter season crop of north western plain zones. In UP ranks first in respect of crop coverage area 9.64 million hectares and production 30.00 million tones but average productivity is $3.11 \mathrm{t} \mathrm{ha}^{-1}$ (FAO, STATE -2011-12).

In recent years, concept of involving Integrated Nutrient Management (INM) combined use of organic sources and chemical fertilizers has been developed. The use of adequate dose of organic sources coupled with chemical fertilizers is expected to ensure optimum growth condition under intensive pattern of farming using high yielding varieties.

Among all essential nutrients nitrogen, phosphorus, potash, zinc and sulphur are the most important for the plants and also most limiting nutrients in Indian soils due to less and imbalance application. So application of $\mathrm{N} P \mathrm{~K} \mathrm{Zn}$ and $\mathrm{S}$ containing fertilizers in 
proper proportion is necessary to augment the productivity of wheat.

Sodic soil reclamation is successful using inorganic amendments like gypsum and pyrite, but these amendments are expensive and not easily accessible to many poor farmers. We explored the possibilities of integrating "Organic manures", an easily accessible organic by-product of sugar factories and rich in sulphur and zinc with salt-tolerant wheat varieties to improve the productivity of sodic soil. This technology was successfully validated in farmer's fields across several villages target hot spots of sodic soil in Eastern Utter Pradesh. A farmer participatory approach was followed for technology validation and to ensure adoption. The promising wheat varieties preferred by the formers were NW1014, NW1067 and KRL99 which produced yields ranging between 3-4.5 $\mathrm{t} \mathrm{ha}^{-1}$.

The INM with zinc sulphate under such conditions seems to be more beneficial for wheat cultivation with respect to yield, uptake and utilization of nitrogen and zinc along with improvement in soil health. Since organic manures are known to improve the soil health such as increased water retention and supply of the nutrients, hence the use of these in the form of Farm Yard Manure (FYM) and Vermicompost will certainly boost up crop production from the soil. The organic material such as Vermicompost and FYM available in abundance at nominal cost in eastern Uttar Pradesh may be the alternative for the organic manures.

\section{Materials and Methods}

The experiment was conducted during 201112 at farm of Narendra Deva University of Agriculture and Technology, Kumarganj, Faizabad (U.P.). The experiment was consisting of eight (8) treatment viz., $\mathrm{T}_{1}$ (control), $\mathrm{T}_{2}(100 \% \mathrm{RDF}), \mathrm{T}_{3}(75 \% \mathrm{RDF}+$ $25 \%$ FYM-N), $\mathrm{T}_{4}(50 \%$ RDF $+50 \%$ FYM$\mathrm{N}), \mathrm{T}_{5}(25 \% \mathrm{RDF}+75 \% \mathrm{FYM}-\mathrm{N}), \mathrm{T}_{6}(75 \%$ $\mathrm{RDF}+25 \%$ Vermicompost-N), $\mathrm{T}_{7}(50 \% \mathrm{RDF}$ $+50 \%$ Vermicompost $-\mathrm{N}), \mathrm{T}_{8}(25 \% \mathrm{RDF}+$ $75 \%$ Vermicompost $-\mathrm{N}$. These treatments were evaluated in Randomized Block Design having four replications. The soil of experimental field was silty loam in texture with low in organic carbon $0.27 \%$, Available $\mathrm{N}$, Available $\mathrm{P}_{2} \mathrm{O}_{5}$, Available $\mathrm{K}_{2} \mathrm{O} @$ 194.01, 13.86, 242.56 Kg ha ${ }^{-1}$ respectively and with pH 8.90 and EC $0.40 \mathrm{dSm}^{-1}$. Recommended dose of fertilizers for wheat was @ 120, 60, 40 and $25 \mathrm{Kg} \mathrm{ha}^{-1} \mathrm{~N}, \mathrm{P}_{2} \mathrm{O}_{5}, \mathrm{~K}_{2} \mathrm{O}$, and $\mathrm{ZnSO}_{4}$, respectively. The wheat variety NW 1014 was sown $17.5 \times 5.0 \mathrm{~cm}$ apart using a seed rate of $125 \mathrm{~kg} \mathrm{ha}^{-1}$ in $15^{\text {th }}$ December and harvested after 120 days crop age. Observations on yield parameter of wheat were recorded. Available $\mathrm{N}, \mathrm{P}_{2} \mathrm{O}_{5}$ and $\mathrm{K}_{2} \mathrm{O}$ content in soil at $15 \mathrm{~cm}$ depth from each plot after wheat harvest was estimated separately.

\section{Results and Discussion}

Various levels of nitrogen as inorganic fertilizer alone and their combination with FYM and Vermicompost significantly influenced the plant height, yield attributes, grain yield and straw yield higher over all stages except harvest index (Table 1). The highest plant height was recorded under treatment $\mathrm{T}_{6}(110.25 \mathrm{~cm})$ applied $75 \% \mathrm{RDN}$ $\mathrm{F}+25 \% \mathrm{~N}$ through Vermicompost, minimum plant height $(86.25 \mathrm{~cm})$ was recorded in $\mathrm{T}_{1}$ (control) at maturity stage. The increasing plant height at different stages under various inorganic fertilizer levels alone and in combination with organic sources was due to increased availability of nutrients in adequate amount at different growth stages to wheat crop. The similar results finding of Singh et al., (2012), the maximum number of effective tillers was recorded under treatment $\mathrm{T}_{6}(7.25)$ applied $75 \% \mathrm{RDN}-\mathrm{F}+25 \% \mathrm{~N}$ 
through Vermicompost, which was significantly superior over all treatments, while least in $\mathrm{T}_{1}$ (control). Similar result was observed of Singh et al., (2010). The maximum spike length was observed with $\mathrm{T}_{6}$ (75\% RDN-F + $25 \%$ N-Vermicompost) and, which was statistically at par with $\mathrm{T}_{2}(100 \%$ RDN-F), $\mathrm{T}_{3}(75 \%$ RDN-F + $25 \%$ N-FYM), $\mathrm{T}_{4}\left(50 \% \mathrm{RDN}-\mathrm{F}+50 \% \mathrm{~N}-\mathrm{FYM}\right.$ and $\mathrm{T}_{7}(50$ $\%$ RDN-F + $50 \% \mathrm{~N}$-Vermicompost) and significantly superior over the rest of treatments.

The maximum number of grains spike ${ }^{-1}$ was recorded under treatment $\mathrm{T}_{6}$ (46.00) applied $75 \%$ RDN-F $+25 \% \mathrm{~N}$ through Vermicompost which was statistically at par with $\mathrm{T}_{2}(100 \% \mathrm{RDN}-\mathrm{F}), \mathrm{T}_{3}(75 \% \mathrm{RDN}-\mathrm{F}+$ $25 \% \mathrm{~N}$ through FYM), while least in $\mathrm{T}_{1}$ (control). The use of organic manure with chemical fertilizers are accelerate the uptake of essential nutrients such as N, P, and K by crop plants and improve the physical properties of the soil and also increased the supply of plant growth hormones.

The maximum grain and straw yield was recorded under treatment $\mathrm{T}_{6}(75 \% \mathrm{RDN}-\mathrm{F}+$ $25 \% \mathrm{~N}$-Vermicompost), grain yield was statistically at par with $\mathrm{T}_{2}(100 \% \mathrm{RDN}-\mathrm{F})$ and $\mathrm{T}_{7} \quad(50 \%$ RDN-F $+50 \% \quad \mathrm{~N}-$ Vermicompost) and Straw yield was statistically at par with $\mathrm{T}_{2}(100 \% \mathrm{RDN}-\mathrm{F}), \mathrm{T}_{7}$ (50\% RDN-F + $50 \%$ N-Vermicompost) and $\mathrm{T}_{8}(25 \%$ RDN-F $+75 \%$ N-VC) and Significantly superior over the rest of treatments, while the minimum grain and straw yield was recorded under treatment $T_{1}$ (Control). The beneficial effect of organic manures on yield might be due to additional supply of plant nutrients as well as physical and biological properties of soil, Datt et al., (2003). Nayaka et al., (2012) The study indicated that application of recommended dose of $\mathrm{N}-\mathrm{P}-\mathrm{K}$ either through inorganic fertilization or through inorganic fertilizer $\mathrm{N}$ -
$\mathrm{P}-\mathrm{K}$ with $50 \%$ of nitrogen substituted by FYM or crop residue or green manure to rice and $\mathrm{N}-\mathrm{P}-\mathrm{K}$ to wheat improved the SOC, POC, MBC concentration, total SOC stocks and their sequestration rate.

The bulk density of soil decreased with use of the different treatments combination of inorganic fertilizers and organic manure as compared to control. Minimum value of soil bulk density was found in $\mathrm{T}_{5}(25 \% \mathrm{RDN}-\mathrm{F}+$ $75 \%$ N-FYM) than control, while, maximum bulk density was recorded in control than other treatments. The application organic manures improved soil physical properties and act as an ameliorative agent to reduce the compaction of soil. The soil $\mathrm{pH}$ declined slightly in all the treatments containing organic and inorganic treatments from initial level of 8.90 to 8.71.the decrease soil $\mathrm{pH}$ from 8.87 to 8.71 with maximum being recorded in treatment $\mathrm{T}_{5}(25 \% \mathrm{RDN}-\mathrm{F}+75 \% \mathrm{~N}-\mathrm{FYM})$ as compared to other treatments. The release of organic acids during decomposition of these organic manures might have resulted in slightly decline in soil pH Babu et al., (2007).

Organic carbon: The maximum organic carbon was recorded in treatment $\mathrm{T}_{5}(25 \%$ $\mathrm{RDN}-\mathrm{F}+75 \% \mathrm{~N}-\mathrm{FYM}$ ) followed by other treatments. We have seen that the organic carbon contain of the soil can be improved by INM technology ranging from 0.032 to $0.06 \%$ year ${ }^{-1}$ by application of FYM.

The highest amount of available nitrogen, phosphorus and potassium in soil recorded in treatment $\mathrm{T}_{8}(25 \% \mathrm{RDN}-\mathrm{F}+75 \% \mathrm{~N}-$ Vermicompost) 220.51, 15.93 and $260.44 \mathrm{Kg}$ $\mathrm{ha}^{-1}$ respectively. Which was significant superior with followed by rest of all treatments, while minimum in treatment $\mathrm{T}_{1}$ (control) $167.49,12.90$ and $242.56 \mathrm{Kg} \mathrm{ha}^{-1}$ respectively. 
Table.1 Effect of different treatments on wheat plants

\section{Treatments}

\begin{tabular}{|c|c|c|c|c|c|c|c|c|c|}
\hline & 30 DAS & $60 \mathrm{DAs}$ & 90DAS & $\begin{array}{l}\text { No. of effective } \\
\text { (cm) }\end{array}$ & $\begin{array}{l}\text { Spike length } \\
\text { spike }^{-1}\end{array}$ & $\begin{array}{l}\text { No. of grain } \\
\qquad\left(\mathrm{q} \mathrm{ha}^{-1}\right)\end{array}$ & $\begin{array}{l}\text { Grain yield } \\
\qquad\left(\mathrm{q} \mathrm{ha}^{-1}\right)\end{array}$ & $\begin{array}{c}\text { Straw yield } \mathrm{H} \\
(\%)\end{array}$ & $\begin{array}{l}\text { Harvest index } \\
\text { tillers plant }{ }^{-1}\end{array}$ \\
\hline Control & 13.71 & 50.50 & 86.25 & 2.75 & 8.25 & 35.25 & 20.63 & 31.45 & 39.84 \\
\hline $100 \%$ RDN-F & 17.29 & 66.50 & 109.00 & 5.25 & 9.50 & 45.25 & 37.38 & 52.78 & 41.50 \\
\hline $75 \%$ RDN-F + 25\%N-FYM & 15.99 & 65.50 & 106.50 & 5.00 & 9.25 & 41.50 & 33.19 & 47.46 & 41.15 \\
\hline $50 \%$ RDN-F + 50\% N- FYM & 15.33 & 63.00 & 99.75 & 4.50 & 9.00 & 41.25 & 31.68 & 45.63 & 40.98 \\
\hline $25 \%$ RDN-F + 75\% N- FYM & 14.49 & 58.40 & 97.25 & 3.75 & 8.50 & 40.50 & 29.29 & 41.54 & 41.38 \\
\hline $75 \%$ RDN-F+ 25\% N-VC & 16.03 & 67.25 & 110.25 & 7.25 & 9.75 & 46.00 & 38.33 & 54.57 & 41.20 \\
\hline $50 \%$ RDN-F + 50\% N-VC & 15.66 & 62.75 & 103.25 & 4.50 & 9.25 & 43.50 & 35.44 & 52.81 & 40.16 \\
\hline $25 \% \mathrm{RDN}-\mathrm{F}+75 \% \mathrm{~N}-\mathrm{VC}$ & 15.11 & 60.50 & 98.50 & 4.00 & 8.75 & 39.25 & 33.06 & 52.73 & 38.54 \\
\hline SEm \pm & 0.34 & 1.40 & 2.27 & 0.39 & 0.28 & 1.47 & 0.97 & 1.39 & 1.33 \\
\hline $\mathrm{CD}(\mathrm{P}=0.05)$ & 1.00 & 4.11 & 6.68 & 1.11 & 0.82 & 4.31 & 2.84 & 4.08 & NS \\
\hline
\end{tabular}

DAS - Days after sowing, RDN-F - recommended dose of nitrogen through fertilizers, N-FYM - nitrogen through farm yard manure, N - VC - nitrogen through vermi-compost.

\section{Plant height (cm)Yield attributes}

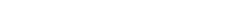


Table.2 Effect of different treatments on soil properties

\begin{tabular}{|c|c|c|c|c|c|c|c|}
\hline Treatments & $\begin{array}{c}\text { Bulk De } \\
\left(\operatorname{gcc}^{-1}\right)\end{array}$ & $\begin{array}{l}\text { EC } \\
\text { (dS }\end{array}$ & $\mathbf{p H}$ & $\begin{array}{l}\text { OC } \\
(1: 2.5)\end{array}$ & $\begin{array}{c}\text { Available N } \\
(\%)\end{array}$ & $\begin{array}{c}\text { Available P } \\
\qquad\left(\mathrm{Kg} \mathrm{ha}^{-1}\right)\end{array}$ & $\begin{array}{r}\text { Available K } \\
\qquad\left(\mathrm{Kg} \mathrm{ha}^{-1}\right)\end{array}$ \\
\hline Control & 1.47 & 0.38 & 8.87 & 0.29 & 167.49 & 12.90 & 236.87 \\
\hline $100 \%$ RDN-F & 1.46 & 0.36 & 8.85 & 0.31 & 211.49 & 15.14 & 265.54 \\
\hline $75 \%$ RDN-F + 25\%N-FYM & 1.44 & 0.35 & 8.83 & 0.34 & 208.72 & 14.01 & 246.58 \\
\hline $50 \%$ RDN-F + 50\% N- FYM & 1.43 & 0.31 & 8.81 & 0.36 & 214.54 & 14.96 & 250.58 \\
\hline $25 \%$ RDN-F + 75\% N- FYM & 1.41 & 0.30 & 8.76 & 0.39 & 217.37 & 15.48 & 253.79 \\
\hline $75 \%$ RDN-F+ 25\% N-V & 1.45 & 0.34 & 8.86 & 0.33 & 209.79 & 14.58 & 247.38 \\
\hline $50 \%$ RDN-F + 50\% N-VC & 1.44 & 0.33 & 8.84 & 0.35 & 215.82 & 15.20 & 257.39 \\
\hline $25 \%$ RDN-F + 75\% N-VC & 1.42 & 0.32 & 8.79 & 0.37 & 220.51 & 15.93 & 260.44 \\
\hline SEm & 0.01 & 0.01 & 0.04 & 0.01 & 1.05 & 0.09 & 0.50 \\
\hline $\mathrm{CD}(\mathrm{P}=0.05)$ & 0.03 & NS & 0.12 & 0.03 & 3.08 & 0.27 & 1.47 \\
\hline Initial value & 1.47 & 0.40 & 8.90 & 0.27 & 194.01 & 13.83 & 242.56 \\
\hline
\end{tabular}

DAS - Days after sowing, RDN-F - recommended dose of nitrogen through fertilizers, N-FYM - nitrogen through farm yard manure, N - VC nitrogen through vermi-compost. 
Increase in available nitrogen with Vermicompost (organic manures) application might be attributed to direct addition of nitrogen through Vermicompost to available pool of the soil. The increase in available phosphorous content of soil due to the incorporation of organic manures may be attributed to the direct addition of phosphorous as well as solubilization of native phosphorous through release of various organic acids Sharma et al., 2005. The beneficial effect of Vermicompost on available potassium status may be ascribed to the direct potassium addition in the potassium pool of the soil.

In conclusion, integrated use of organic manures viz, Vermicompost and FYM along with chemical fertilizers increased the yield and uptake of nutrient by wheat crops significantly over sole use of chemical fertilizers. Substantial improvement was recorded in organic carbon available N,P,K where significantly higher in case of plots which had received either Vermicompost or FYM in combination with chemical fertilizers then the plots which had received chemical fertilizers only. It could also conclude from the effects on yield nutrient content, and soil fertility that application of Vermicompost performed better than farm yard manure.

\section{References}

Babu, M.V.S., Reddy, C.M., Subramanyam, A., and Balaguravaiah, D. 2007. Effect of organic and inorganic fertilizers on soil properties and yield of sugarcane. J. Indian Society of Soil Sci., 55: 161-166.

Datt, N., Sharma, R.P. and Sharma, G.D. 2003. Effect of supplementary use of FYM along with chemical fertilizers on productivity and nutrient uptake by vegetable pea (Pisumsativumvararvense) and build-up of soil fertility in LahaurVally of Himanchal Pradesh. Indian J. Agri. Sci., 73: 266-268.

FAO. 2012. Annual report.

Nayaka, A.K., B. Gangwara, Arvind, K. Shuklab, Sonali, P., Mazumdara, AnjaniKumarb, R., Rajab, Anil Kumara, Vinod Kumara, P.K., Raia and Udit Mohana. 2012. Long-term effect of different integrated nutrient management on soil organic carbon and its fractions and sustainability of rice-wheat system in Indo Gangetic Plains of India. Field Crops Res., 127: 129-139.

Sharma, R.P., Sharma, Akhilesh and Sharma, J.K. 2005. Productivity, nutrient uptake, soil fertility and economics as affected by chemical fertilizers and farm yard manure in broccoli (Brassica oleraceavar italica) in an Entisol. Indian J. Agri. Sci., 75: 576579.

Singh, R.V. and Kumar, R. 2010. Effect of organic and inorganic fertilizers on growth and yield and quality and nutrient uptake of wheat under late sown condition. Progressive of Agri., 10(2): 341-344.

Singh, S.P., Vivek Ravinda Kumar. 2012. Effect of different nutrient sources on yield of wheat (Triticum aestivum L.). Progressive Agri., 12(2): 412-414.

\section{How to cite this article:}

Hanumant Singh, Abhinaw Kumar Singh, Sarware Alam, Tejpratap Singh, V.P. Singh, A.K.S. Parihar and Rajneesh Singh. 2017. Effect of Various Integrated Nutrient Management Models on Growth and Yield of Wheat in Partially Reclaimed Sodic Soil. Int.J.Curr.Microbiol.App.Sci. 6(3): 803-808. doi: https://doi.org/10.20546/ijcmas.2017.603.094 